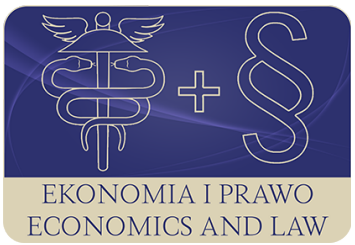

EKONOMIA I PRAWO. ECONOMICS AND LAW Volume 19, Issue 4, December 2020

p-ISSN 1898-2255, e-ISSN 2392-1625

www.economicsandlaw.pl

ORIGINAL ARTICLE

received 30.03.2019; revised 10.02.2020; accepted 31.12.2020

Citation: Łazarczyk, D. (2020). The role of costs' knowledge in the contemporary enterprises.

Ekonomia i Prawo. Economics and Law, 19(4): 725-737. doi:10.12775/EiP.2020.047.

\title{
The role of costs' knowledge in the contemporary enterprises
}

\author{
DAMIAN EAZARCZYK \\ University of Szczecin, Faculty of Economics, Finance and Management, Department of Accounting, \\ ul. Cukrowa 8, 71-004 Szczecin, Poland \\ $\square$ damian.lazarczyk@usz.edu.pl \\ (D) orcid.org/0000-0002-9014-4125
}

\begin{abstract}
Motivation: Contemporary enterprises need useful information to reach success in times of globalization of market economy. Costs are an indispensable economic category, especially in decision process. Costs constitute the wear and tear expressed in the financial measure. Generating costs is reflecting the manner of the conducting business activities. Costs are incurred to reach the income. Cost is inevitable, whereas income is probable. Therefore, cost control and cost management matter. The information about cost is primarily used for: regulating the prices, closing the decisional cost and result accounts, providing 'activity based costing' analyses (including contemporary 'time-driven activity based costing'), as well as budgeting the operational and control costs. The development of cost accounting systems results from globalization and growth in importance of the knowledge in managing contemporary enterprises. Essential premises of the development include: loss of timelines of the reporting cost accounting, rise in the automation and technology in the production, rise in the share of indirect costs in all-in costs and increase in the usefulness of the knowledge for the costs indirect, dynamic growth of the role of information in the business administration, increase in the costing awareness of managers.

Aim: This article's research aim is to explain the influence of cost accounting instrumentation on managing contemporary enterprises, including the decision-making process. Results: Knowledge about costs getting from cost accounting, have a significant impact on a contemporary enterprise management.
\end{abstract}

Keywords: cost accounting; a knowledge about costs; economics JEL: M41; All; A2 


\section{Introduction}

Modern enterprises should effectively manage the organization to achieve economic success The company's mission is a paradigm of its existence and activity, including its economic part, while the implementation of the main objective and intermediate goals set by the owners and managers allows for wise and effective management at the strategic and operational level. This is also the implication of dynamic changes in the economic perception the regional and continental level regarding strong competition in the markets in the continuous globalization process. At the same time, man is a witness to technological progress, which also affects the methods and techniques of managing a modern enterprise. This entails the need to improve decision-making processes. In modern times, such role is played by the knowledge. The knowledge is an ambiguous concept, as summarized in table 1 .

Semantic knowledge goes beyond information, because it implies the ability to solve problems, it is the premises of undertaken actions and reasoning. Knowledge is intuitive, subjective and dynamic, which allows us to draw conclusions into the future, while data and information are an objective reflection of the actual state. Knowledge is the application of information in the enterprise's practice and its quality manifests itself in action (Morawski, 2006, p. 18). However, in the aspect of obtaining and using processed data, knowledge is identified with the information sensu stricto.

Today's enterprises need utilitarian information to succeed in a globalizing market. At the same time, the cost of the economy is an indispensable element in the effective management of the modern organization. Contemporary economic aspects cannot be ignored, especially in the absence of unlimited availability of goods, i.e. rarity, profitability categories, i.e. the profitability of economic activity and the rationality of using controlled resources. The need to obtain cross-sectional information on the costs of operations determines the decision-making processes in business management, including its sine qua non activity, i.e. production and sales. Costs as consumption of fixed and current assets are certain, while realized revenues - probable. Reaching the direct reasons for incurring costs should guide managers in expanding knowledge and intuition, that is, wisdom in making decisions, including economic decisions. The premise of striving for success in a modern enterprise may be related to the use of modern methods of cost management and the instrumentation of the cost accounting subsystem, as well as the over-functional management tool, i.e. controlling. The dependencies between the cost accounting system in the management system and the relations between elements of the system are shown in scheme 1 .

The purpose of this article is to answer the following questions:

- What impact does the cost accounting system have on the management of modern enterprises?

- What is the role of knowledge about the consumption of resources and how to use this knowledge? 
- Is it possible to assign a cost to a human being?

The paper at the beginning discusses the creation of knowledge about costs in the cost accounting model. Then, the systems and formulas for calculating costs were characterized through the prism of the decision-making process with the focus on the suitability of cost information from cost accounting in the management of a modern enterprise.

\section{Methods}

In the article the research methods were chosen:

- reviewing and evaluating domestic and international literature on cost accounting, management accounting and knowledge about costs;

- deductive analysis and inductive analysis; analysis of logical.

The conclusions were presented in graphical form at Appendix.

\section{Literature review}

\subsection{Creation of knowledge about costs in a modern enterprise}

The increase of interest on the part of the management of modern enterprises in incurred costs, which entails expenditures in tempora or ex ante, is correlated with information needs, including the awareness that the biggest role in increasing profit and improving profitability is played by the optimization activities in the field of costs and, consequently, efficient cost management.

According to Nowak (2003, p. 9), common elements can be identified in the concept of cost management, i.e.:

- the subject of cost management includes costs borne by the enterprise for the implementation of various economic processes;

- the primary information base for cost management is related to appropriate cost accounting systems that take into account the specific information needs of managing various areas of the company's operations;

- cost budgeting is an important cost management tool including cost planning and control, and analysis of deviations between real costs and planned costs

- the basic objective of basket management is to increase the efficiency of using the company's resources, which should contribute to increasing profit and increasing the value of the company;

- the main way to achieve the cost management objective is to improve the rationality of costs incurred through various measures aimed at reducing costs. Creation of cost knowledge starts with measurement and valuation. It's about answering the question: how much is something worth and why is it worth this amount (e.g. in PLN)? According to Sadowska (2019, p. 81) standardized methods and measuring tools ensure objectivity, reliability and compa- 
rability of information obtained as a result of measurement. In addition, they contribute to the creation of an international business language that can be used by various entities and stakeholders by measuring the same categories. Accounting system uses such methods and instruments. The role of accounting in the theory of economic measurement is of fundamental importance.

Human knowledge about, for example, wage costs of work, i.e. gross costs of wages, including charges for remuneration in the form of insurance premiums due to the pension body, obtained through financial reporting, gives an awareness of the labour price. It makes it possible to answer the question: how much it costs to do a job and how much it costs to involve human resources in the process of managing a modern enterprise. This implies another question: whether a company can afford the timely payment of remuneration to employees and repayment of public law liabilities?

Information on the consumption of labour, land and capital resources is therefore of vital importance in the effective management of resources. Efficient cost management requires appropriate knowledge of the essence, systems, decision-making applications, as well as variations of cost accounting, which affect the scope and nature of information on costs and the possibilities of their use in management (Kiziukiewicz, 2019, p. 13).

The essence of the cost boils down to the simultaneous occurrence of the following components:

- consumption of resources (assets, property);

- monetary measure - value (i.e. in PLN);

- economic goal - costs are incurred in order to achieve an advantage, i.e. revenue;

- unit of time, e.g. month, quarter.

They are often classified in the creation of knowledge about costs. Various criteria for classifying costs are available, which is justified by the principle of 'different costs for different purposes'. The choice of a given criterion is made depending on the information needs of users about the costs. The general classification of costs is included table 2 .

\subsection{Cost accounting model}

The cost account is the total of actions in the accounting information system related to (Nowak, 1999, pp. 15-16; Sadowska, 2017, p. 179; Sawicki, 2000, pp. 87-89):

- measurement (quantitative and valuable);

- valuation (determination of value in PLN);

- documentation (accounting evidence);

- records (recording, booking operations);

- settlement (division into various cost systems);

- calculation (determination of unit cost, e.g. PLN/m);

- reporting (financial statements, including profit and loss account); 
- analysis (research and evaluation);

- control (verification of the correctness of processes in the cost account);

- planning (budgeting process);

- operating costs in a modern enterprise.

The above activities form the purpose of the cost accounting subsystem, i.e. developing and providing multi-sectional information on the consumption of assets. Actions from 1) to 6) are related to the so-called calculation of costs sensu stricto, i.e. a source of information about costs. On the other hand, actions from 1) to 9) is a cost calculation sensu largo - the use of information, which implies knowledge of costs.

According to Nowak (2003, p. 10) 'the cost accounting model is a set of rules and procedures according to which the incurred costs are measured and the cost information is transformed in order to adapt it to the specific needs of information users'. The general model of the cost account is illustrated in scheme 2.

The main task of the model is to highlight the variables explaining the consumption of components: fixed assets (e.g. depreciation) and current assets and to enable the measurement of the relationship between these variables and costs, i.e. the explained variable. This applies to the examination and evaluation of already existing processes that shape information about costs as well as planning. The use of the cost accounting model is to improve the effectiveness of the intended activities. The pursuit of learning about the immediate causes of resource consumption determines the development of the model (system) of the cost account. This development is reflected in the following aspects:

- continuous improvement of existing procedures and principles of processing data on costs;

- introduction to the accounting theory and practice of new methods of cost management and cost accounting models;

- change in the direction of using information about costs, from ex post orientation to prospective and anticipatory orientation.

\subsection{Cost accounting systems: trends of changes}

The management of a modern enterprise is strongly correlated with the decision-making process. The term 'decision-making process' means any actions that result in a decision to resolve a specific problem. The decision-making process includes the development and analysis of a set of solution variants, i.e. variants of decisions and the choice of the best ones (Sawicki, 1998, p. 69). The so-called problem-related cost accounts are distinguished in reference to the above, the scheme of which is presented in scheme 3 .

The pursuit of knowledge development on the costs and satisfaction of information needs caused changes and decomposition of the traditional model of cost accounting. Systems and variations of cost accounting have evolved, which is illustrated in scheme 4 . Table 3 includes variations of cost accounting and their applications. 
Modern enterprises operating in the conditions of the globalization process are increasingly using the Activity-Based Costing (ABC) system and its timebased modification. The activity-based costing model should faithfully match the existing state of the organization (Piechota, 2004, p. 188). As emphasized by Kochański (2018, p. 127), the activity costs accounting is a milestone in the evolution of the philosophy of cost management using a cost method that is both reporting (systematic) and management in nature at the same time. The latest approach does not reject its assumptions; on the contrary it integrates $\mathrm{ABC}$ with the German calculation of planned marginal costs as part of the resource cost accounting.

The logic of the ABC model operation is based strictly on the relationship: resources (assets) - activities (processes) - effects (products and services). Its modified variety, i.e. 'time-driven activity-based costing' (TDABC). This account uses time to settle resource costs. The TDABC model avoids the costly, time-consuming and subject-biased questionnaire about activities typical of a conventional accounting. Time equations are used to directly and automatically assign resource costs to performed activities and processed transactions (Kaplan \& Anderson, 2008, p. 23).

In today's enterprises, the knowledge about costs is usually necessary to:

- setting prices of work products (e.g. finished goods, services, production in progress) - the price should cover total costs (variable and fixed) and allow for the achievement of a margin. Price is a monetary reflection of value. This is the main (next to the sales volume) element of sales revenues. In addition, an important decision criterion is related to the so-called lower price limit, i.e. the lowest price level, for which it is profitable to produce and sell a given product;

- the analysis of 'costs-sales volume-profit', which is a method of studying the relation between changes in sales volume and changes in costs and profit (cf. Horngren et al.,2012, p. 77);

- solving short-term problem accounting (decisive) of costs;

- analysis (research and evaluation) of units responsible for costs at the levels: assortments and their groups, areas and types of activity, work-places, branches, departments, the whole enterprise;

- budgeting costs in the short term - determining the budget of fixed costs for a given financial year and variable costs; cost control and planning;

- knowledge and experience in the field of cost creation. Contemporary tendencies in creating knowledge about costs are reduced to the assignment of the amount of the cost to man. Man is also subjected to consumption. Thus, consumption affects a person, but expenses to be borne, affecting a fundamental issue, i.e. health, are still unknown. 


\section{Conclusion}

Knowledge about costs plays an important role in modern enterprises. Knowledge about costs getting from an information system, have a significant impact on a contemporary enterprise management. Nowadays, information and its use is a key element conditioning success on a globalizing market in a permanently changing world. Effective performance of planning, organizing, motivating and controlling functions is supported by the accounting information system and cost accounting meta-system. The general model of cost accounting, along with its variations, plays the role of satisfying the needs of knowledge about costs in a given unit of time and in a given environment. The consequences of the decisions made are related to costs and expenses. The cost accounting instrument is evolving. The use of the selected cost accounting model allows for proper planning of the use of controlled resources, setting standards and ensuring proper measurement and adequate valuation as well as effective cost and profitability management of the modern enterprise. Without knowledge of the amount of costs, it is not possible to set the right prices or make decisions, especially financial ones. Knowledge and experience are fundamental features to achieve success in the modern economic and social environment (cf. Sadowska et al., 2017, p. 126). Wise management of costs is the basis for rational management in business as well as in life.

\section{References}

Armstrong, M. (2003). A handbook of human resource management practice. London: Kogan Page.

Blackler, F. (1995). Knowledge, knowledge work and organizations: an overview and interpretation. Organization Studies, 16(6). doi:10.1177/017084069501600605.

Davenport, T.H., \& Prusak, L. (1998). Working knowledge: how organizations manage what they know. Boston: Harvard Business School Press.

Horngren, C.T., Datar, S.M., \& Rajan, M. (2012). Cost accounting: a managerial emphasis. Boston: Prentice Hall.

Jarugowa, A., Malc, W., \& Sawicki, K. (1983). Rachunek kosztów. Warszawa: PWE.

Kaplan, R.S., \& Anderson, S.R. (2008). Rachunek kosztów dziatań sterowany czasem: TDABC time-driven activity-based costing: prostsza i bardziej skuteczna droga do większych zysków. Warszawa: PWN.

Kiziukiewicz, T. (2019). Koszty w zarządzaniu przedsiębiorstwem. In W. Gos, T. Kiziukiewicz, P. Mućko, \& B. Nadolna (Eds.), Zarządzanie kosztami: teoria i dobre praktyki. Warszawa: Wolters Kluwer.

Kochański, K. (2018). Rachunek kosztów działań. In B. Sadowska (Ed.), Rachunkowość zarządcza $w$ systemie informacyjnym przedsiębiorstwa. Warszawa: CeDeWu. 
Morawski, M. (2006). Istota pojęcia wiedza. In G. Kobyłko, \& M. Morawski (Eds.), Przedsiębiorstwo zorientowanie na wiedzę. Warszawa: Difin.

Nowak, E. (1999). Rachunek kosztów. Wrocław: Ekspert.

Nowak, E. (2003). Model rachunku kosztów a potrzeby informacyjne zarządzania. Prace Naukowe Akademii Ekonomicznej we Wroctawiu, 984.

Piechota, R. (2004). Rachunek kosztów działań. In E. Nowak, R. Piechota, \& M. Wierzbiński (Eds.), Rachunek kosztów w zarządzaniu przedsiębiorstwem. Warszawa: PWE.

Probst, G., Raub, S., \& Romhardt, K. (2002). Zarządzanie wiedza w organizacji. Kraków : Oficyna Ekonomiczna.

Sadowska, B. (2017). Rachunek kosztów logistycznych w przedsiębiorstwie. Warszawa: CeDeWu.

Sadowska, B. (2019). Rachunkowość podmiotów gospodarki komunalnej z perspektywy ekonomii zrównoważonego rozwoju: pomiar, ewidencja, raportowanie. Warszawa: CeDeWu.

Sadowska, B., Szczypa, P., Nowak, M., \& Adamowicz, K. (2017). Forest education as the manifestation of entrepreneurship of the state forests national forest holding. Intercathedra, 33(4).

Sawicki, A. (1998). Informacyjne potrzeby zarządzania firmą a sprawozdawczość finansowa. In K. Sawicki (Ed.), Polityka bilansowa i sprawozdawczość finansowa $w$ zarządzaniu firma. Wrocław: Ekspert.

Sawicki, K. (2000). Analiza kosztów firmy. Warszawa: PWE.

Urlich, D. (1998). A new mandate for human resources. Harvard Business Review, January-February.

Wiig, K.M. (1993). Knowledge management foundations: thinking about thinking: how people and organizations create, represent, and use knowledge. Arlington: Schema Press.

\section{Acknowledgements}

Author contributions: author has given an approval to the final version of the article.

Funding: this research was undertaken as part of the Doskonalenie jakości badań naukowych w naukach ekonomicznych ze szczególnym uwzględnieniem sektora ustug project and was fully funded by a grant (RID/WZIEU/2019/1/071).

Note: the results of this study were presented at 10th International Conference on Applied Economics Contemporary Issues in Economy (June 27-28, 2019, Torun, Poland). 


\section{Appendix}

Table 1 .

\section{Selected definitions of knowledge}

\begin{tabular}{lc}
\hline Author & Definition \\
\hline Armstrong (2003, pp. 161-162) & $\begin{array}{r}\text { Knowledge is an information submitted for productive use. It is of individual } \\
\text { nature and is often difficult to embrace and may be elusive. }\end{array}$ \\
\hline Blackler (1995, pp. 16-36) & $\begin{array}{c}\text { Knowledge is comprehensive and exhaustive, explicit and hidden, shared } \\
\text { and personal, physical and mental, static and dynamic, verbal and encrypted. }\end{array}$ \\
\hline Wrlich (1998, pp. 124-134) & $\begin{array}{c}\text { Knowledge has become a direct competitive advantage for companies offering } \\
\text { ideas and relationships. }\end{array}$ \\
\hline Davenport \& Prusak (1998, p. 5) & $\begin{array}{c}\text { Knowledge consists of truths and beliefs, views and concepts, judgments } \\
\text { and expectations; methodology and know-how. } \\
\text { priately selected information, and expert insight into an issue that provides } \\
\text { a framework for assessing and integrating new experiences and information. }\end{array}$ \\
\hline $\begin{array}{c}\text { Knowledge is generally the awareness and skills used by the individuals } \\
\text { to solve problems. It covers both theoretical and practical elements and, at } \\
\text { the same time, general principles and detailed instructions on how to proceed. } \\
\text { Knowledge is based on information and data. However, the basic difference } \\
\text { between them and knowledge is that the latter is always associated with a par- } \\
\text { ticular person. It is the work of individuals and represents their beliefs about } \\
\text { cause-and-effect relationships. }\end{array}$ \\
Probst et al. (2002, p. 13)
\end{tabular}

Source: Own preparation based on Morawski (2006, pp. 14-15).

Table 2.

\section{Basic classification of costs}

\begin{tabular}{ll}
\hline \multicolumn{1}{c}{ Classification criterion } & \multicolumn{1}{c}{ Division of costs } \\
\hline & Reporting objectives \\
\hline & - operating costs; \\
& - financial activity costs; \\
type of activity & - investment activity costs (material investments); \\
& - costs related to special funds. \\
& - purchase costs; \\
& - production costs; \\
& - management costs; \\
the area of activity (objective of incurring) & - sales costs. \\
\hline & - normal (regular) operating costs; \\
& - other operating cost; \\
economic activity & - financial costs. \\
\hline internal structure of costs & - simple costs; \\
\hline
\end{tabular}




\begin{tabular}{|c|c|}
\hline Classification criterion & Division of costs \\
\hline type of costs & $\begin{array}{l}\text { - depreciation; } \\
\text { - usage of materials and energy; } \\
\text { - external services; } \\
\text { - taxes and fees; } \\
\text { - remuneration; } \\
\text { - social security and other benefits; } \\
\text { - other costs by type. }\end{array}$ \\
\hline costs creation places & $\begin{array}{l}\text { - costs of basic departments; } \\
\text { - costs of auxiliary departments; } \\
\text { - management costs; } \\
\text { - purchase costs; } \\
\text { - sales costs. }\end{array}$ \\
\hline the manner of relating costs to objects (carriers) & $\begin{array}{l}\text { - direct costs; } \\
\text { - indirect costs. }\end{array}$ \\
\hline the method of inclusion in the financial report & $\begin{array}{l}\text { - product costs (balance sheet assets); } \\
\text { - costs of the period (profit and loss account). }\end{array}$ \\
\hline cost relationship with work products & $\begin{array}{l}\text { - individual costs; } \\
\text { - common costs. }\end{array}$ \\
\hline relationship with the revenue achieved & $\begin{array}{l}\text { - costs of obtaining revenues; } \\
\text { - costs not constituting the cost of obtaining revenues. }\end{array}$ \\
\hline \multicolumn{2}{|c|}{ Decision-making objectives } \\
\hline significance of when making decision & $\begin{array}{l}\text { - decision-making costs (relevant); } \\
\text { - non-decision-making costs (irrelevant). }\end{array}$ \\
\hline other decision-making objectives & $\begin{array}{l}\text { - cost of lost profits; } \\
\text { - costs (irreversible); } \\
\text { - discretionary costs (appreciation). }\end{array}$ \\
\hline degree of dependence on production volume & $\begin{array}{l}\text { - overhead; } \\
\text { - variable costs. }\end{array}$ \\
\hline capacity utilisation rate & $\begin{array}{l}\text { - fixed costs (useful); } \\
\text { - fixed costs (not useful). }\end{array}$ \\
\hline cost setting mode & $\begin{array}{l}\text { - ex ante fixed costs (in advance); } \\
\text { - costs fixed in tempora (regular); } \\
\text { - expost costs (after they are incurred). }\end{array}$ \\
\hline & Audit objectives \\
\hline objective and controllability & $\begin{array}{l}\text { - controlled costs (dependent); } \\
\text { - non-controlled costs (independent). }\end{array}$ \\
\hline
\end{tabular}

Source: Own preparation based on Sadowska (2017, pp. 53-60), Sawicki (2000, pp. 83-84). 
Table 3.

Varieties of cost accounting and their applications

\begin{tabular}{|c|c|}
\hline Variety of cost accounting & Application \\
\hline traditional cost accounting & $\begin{array}{l}\text { - full costs (direct and indirect) as part of pricing arrangements; } \\
\text { - ex-post cost analysis as the basis for the development of cost assumptions and their } \\
\text { implementation; } \\
\text { - investment decision-making accounting. }\end{array}$ \\
\hline $\begin{array}{l}\text { partial (variable) cost } \\
\text { accounting }\end{array}$ & $\begin{array}{l}\text { - analysis of the relationship ‘costs-production-profit’; } \\
\text { - break-even point analysis; } \\
\text { - selection of the range and/or production technology; } \\
\text { - other short-term decision-making accounting, such as: special order, problem: } \\
\text { 'create or buy', resignation from a deficient product, transfer rates. }\end{array}$ \\
\hline $\begin{array}{l}\text { future costs accounting } \\
\text { (exante) }\end{array}$ & $\begin{array}{l}\text { - cost management by exceptions (deviations from planning assumptions, budget } \\
\text { budgets); } \\
\text { - the ability to manage costs in real time; } \\
\text { - including risks and uncertainties in the decision-making accounting. }\end{array}$ \\
\hline $\begin{array}{l}\text { activity costs (processes) } \\
\text { accounting }\end{array}$ & $\begin{array}{l}\text { - linking indirect costs to the reasons for their creation; } \\
\text { - 'addressable' cost management; } \\
\text { - 'high' compliance with reality - basics of the activity-based management method } \\
\text { (ABM). }\end{array}$ \\
\hline $\begin{array}{l}\text { products life cycle cost } \\
\text { accounting }\end{array}$ & $\begin{array}{l}\text { - objectivity of profitability evaluation of products; } \\
\text { - cost management at every stage of product life; } \\
\text { - implementation of marketing orientation. }\end{array}$ \\
\hline target costs accounting & $\begin{array}{l}\text { - cost management by exceptions (deviations from the target); } \\
\text { - the ability to manage costs in real time; } \\
\text { - including the risk and uncertainty in the decision-making accounting; } \\
\text { - linking costs with revenue and profitability of products; } \\
\text { - cost benchmarking; } \\
\text { - making strategic choices. }\end{array}$ \\
\hline quality cost accounting & $\begin{array}{l}\text { - quality management; } \\
\text { - quality benchmarking; } \\
\text { - implementation of marketing orientation. }\end{array}$ \\
\hline
\end{tabular}

Source: Own preparation based on Kiziukiewicz (2019, p. 93). 
Scheme 1 .

Relations between cost management and cost accounting, accounting system and controlling

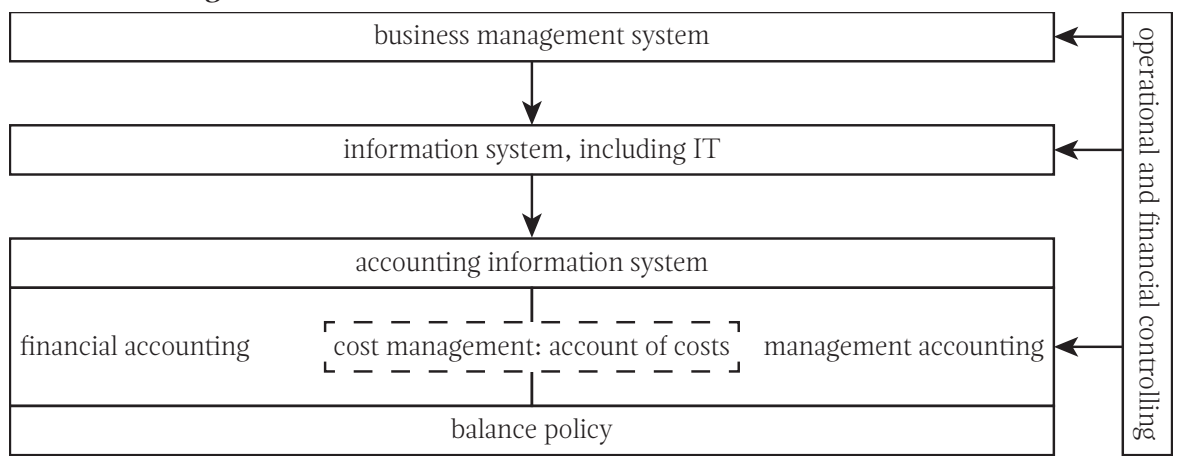

Source: Own preparation.

Scheme 2.

The general cost accounting model

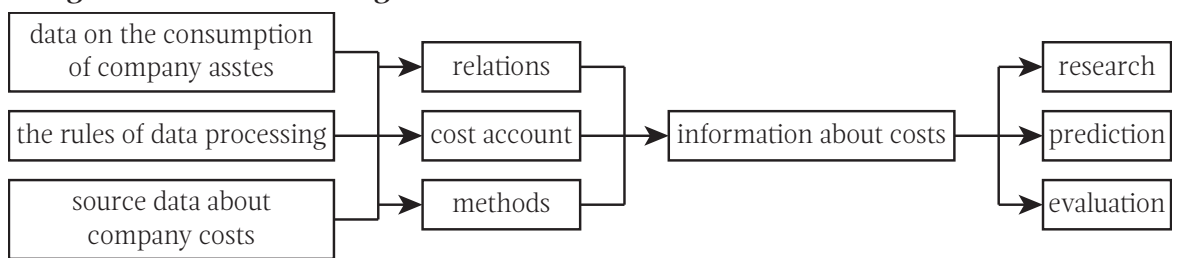

Source: Own preparation.

Scheme 3.

Problem cost accounting

\begin{tabular}{|c|c|c|c|c|}
\hline \multicolumn{5}{|c|}{ problem cost accounting } \\
\hline \multicolumn{5}{|c|}{$\bar{y}$} \\
\hline prediction & \multicolumn{3}{|c|}{ decision-making accounting } & information \\
\hline & & & & accol \\
\hline \multirow{3}{*}{$\begin{array}{l}\text { estimating the most } \\
\text { probable level of new } \\
\text { production costs, } \\
\text { price calculations }\end{array}$} & effectiveness & variant selection & ontimization & \multirow{4}{*}{$\begin{array}{l}\text { occasional } \\
\text { information on the } \\
\text { costs of stock, } \\
\text { machine and } \\
\text { equipment } \\
\text { management, etc. } \\
\text { cost control } \\
\text { by a representative } \\
\text { method }\end{array}$} \\
\hline & of action & \multirow{2}{*}{$\begin{array}{c}\text { choice of technology } \\
\text { or recipe }\end{array}$} & transport problem & \\
\hline & \multirow{2}{*}{$\begin{array}{l}\text { costs and the useful } \\
\text { effect } \\
\text { costs and the quality } \\
\text { of satisfying needs } \\
\text { potential utilization }\end{array}$} & & $\begin{array}{l}\text { allocation of the } \\
\text { production program }\end{array}$ & \\
\hline & & $\begin{array}{l}\text { supply of the factors } \\
\text { of production } \\
\text { (to create or buy or } \\
\text { rent), etc. }\end{array}$ & $\begin{array}{l}\text { minimization of costs } \\
\text { of raw material } \\
\text { components, etc. }\end{array}$ & \\
\hline & $\begin{array}{l}\text { profitability of } \\
\text { investments, etc. }\end{array}$ & & & $\begin{array}{l}\text { value analysis and } \\
\text { cost reduction } \\
\text { measures, etc. }\end{array}$ \\
\hline
\end{tabular}

Source: Own preparation based on Jarugowa et al. (1983, p. 46). 
Scheme 4.

Basics systems and varieties of cost accounting

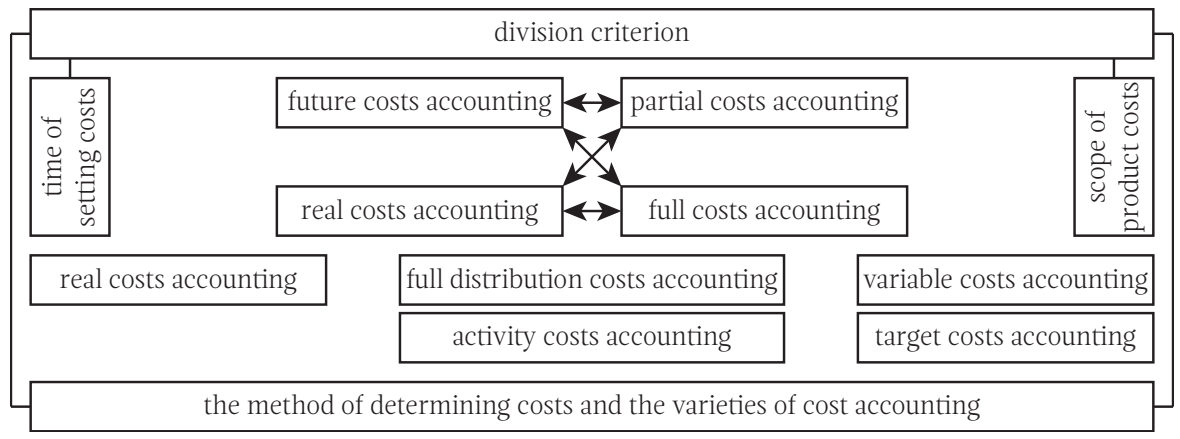

Source: Own preparation based on Sawicki (2000, p. 93). 
